\title{
Design and Analysis of Global Supply Chain Network with Trans-Pacific Partnership under Fluctuating Material Prices
}

\author{
Kengo Nakamura *, Hiromasa Ijuin *, Tetsuo Yamada *, \\ Aya Ishigaki ${ }^{\dagger}$ Masato Inoue $*$
}

\begin{abstract}
Manufacturing firms are becoming more global and forming global supply chain networks in their pursuit of lower production costs and emerging markets including those in Asia. The global supply chain network consists of domestic as well as international suppliers, factories, and markets. Then, the supply chain network applies customs duties when parts and products are transported across overseas borders. In addition, awareness about several cross-border treaties such as regional free trade agreements (FTAs) and the Trans-Pacific Partnership (TPP), is indispensable when designing a global supply chain network. The current fluctuations in oil and energy price also cannot be ignored.

This study analyzes the effect of fluctuating material prices on the global supply chain network under customs duty rates and the TPP regime. First, the global supply chain network with customs duty and TPP is modeled. Next, the model is formulated with integer programming. Finally, sensitivity analysis is conducted in order to investigate the effect on the global supply chain network of the fluctuations in material prices.
\end{abstract}

Keywords: Free Trade Agreement, Customs duty, Bill of materials, Assembly products, Mixed integer programming.

\section{Introduction}

International manufacturing firms form global supply chain networks to reduce production and logistics costs. As suppliers and factories are a part of the global supply chain network, customs duty is applicable on the international transportation of parts and products moving through the global network. For example, the customs duty rate is $2.5 \%$ when passenger cars are exported from Japan to the United States. However, the customs duty rate is $77 \%$ to $83 \%$ when passenger

\footnotetext{
* The University of Electro-Communications, Tokyo, Japan

$\dagger$ Tokyo University of Science, Chiba, Japan

* Meiji University, Kanagawa, Japan
} 
cars are exported from Japan to the Vietnam [1]. In this way, customs duty rates are very high since the industry of emerging countries are protected. In July 2017, the European Union (EU) and Japan have formally agreed an outline Economic Partnership Agreement (EPA) [2]. EPA is a treaty that provides the rules in order to promote trade between specific countries or regions. In this way, the manufacturing firms in each country must consider several treaties on customs duty, such as Free Trade Agreements (FTAs) [3], Economic Partnership Agreement (EPA) and the Trans-Pacific Partnership (TPP) [4]. FTA is an agreement aimed at reducing or eliminating tariffs, etc., between specific countries or regions. TPP is a FTA by originally 12 countries including Japan, Malaysia and the United States, etc. The 12 TPP partner countries represent nearly $40 \%$ of world GDP [5]. There is debates about TPP without USA and Japan-US FTA based on TPP [4].

On the other hand, the material and energy prices are changing drastically in the world. Since June 2014 oil prices have dropped about 65\% in US\$ (about US\$70) [6]. Furthermore, oil prices fluctuation causes a fluctuation in the unit cost of material such as plastics. Therefore, material and energy prices fluctuation affect parts price.

Table 1 shows an analysis of the literature on factors of the global supply chain network including bill of materials (BOM) or customs duty. BOM is a list that includes the cost, size, raw materials, sub-assemblies, sub-components, weight of each part, and the quantities of each needed to manufacture an end product [7]. This study uses BOM to analyze supply chain construction with material prices fluctuates.

Munson and Rosenblatt [8] investigated the effect of global sourcing decisions under local content rules. Abdallah et al. [9] modeled the supply chain that takes into account the facility opening costs and conducted numerical experiments on carbon trading. Urata et al. [10] modeled a global supply chain network with material-based $\mathrm{CO}_{2}$ emissions. However, customs duty and TPP were not considered in these study. Cohen and Lee [11] modeled a basic framework for supply chain network design. Amin and Baki [12] conducted sensitivity analysis of customs duty rates on products and the exchange rate. Tsiakis and Papageorgiou [13] used a customs duty model for transporting goods from factories in six different countries to delivery centers. Hosoda et al. [14] modeled the global supply chain network with a combination of multiple existing FTAs. However, these previous studies did not use a BOM in their analysis.

Cohen et al. [15] modeled a basic framework for supply chain network design including customs duty. However, this study did not consider supplier, factory and market location with regard to transportation distance and cost. Vidal and Goetschalckx [16] proposed model with transfer pricing, and considered imported duty and corporate tax rate. Arntzen et al. [17] considered the international transportation of digital equipment such as notebook PCs and printers. However, production and shipment quantities are not considered in these previous study. Mariel and Minner [18] modeled network designs under the North American Free Trade Agreement (NAFTA) local content requirement. Nakamura et al. [19] [20] modeled the global supply chain network by including the customs duties and TPP/FTAs. However, these previous study did not conduct sensitivity analysis of material prices and related considerations.

This study analyzes the influence of fluctuating material prices on a global supply chain network under TPP by considering the applicability of relevant customs duty rates. First, the global supply chain network with customs duty is modeled by using previous studies [10] [19] [20]. Next, the model is formulated with integer programming [21]. Additionally, BOM, which lists all the parts 
and includes the cost, size, and weight of each part, is prepared by using a 3D-computer aided design (3D-CAD) and an industry census. Finally, sensitivity analysis of material prices is conducted, and after that, the results are discussed in terms of material types and costs for each part.

This paper is organized as follows. Section 2 explains the model and the formulation for the global supply chain network with customs duty and TPP, and Section 3 sets an example problem. Section 4 shows and discusses the relationship between TPP and material prices fluctuation. Section 5 shows results of supplier and factory selection without redesign. Finally, Section 6 summarizes this paper and states future works.

Table 1: A literature review of factors

\begin{tabular}{|c|c|c|c|c|c|c|}
\hline Literature & $\begin{array}{l}\text { Supplier } \\
\text { selection }\end{array}$ & $\begin{array}{l}\text { Factory } \\
\text { location }\end{array}$ & $\begin{array}{l}\text { Production/ } \\
\text { shipment } \\
\text { quantities }\end{array}$ & $\mathrm{BOM}$ & Customs duty & $\begin{array}{c}\text { Sensitivity } \\
\text { analysis of } \\
\text { fluctuating } \\
\text { material prices }\end{array}$ \\
\hline Munson and Rosenblatt (1997) & 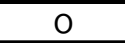 & 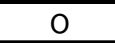 & 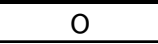 & 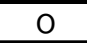 & 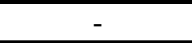 & 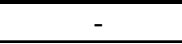 \\
\hline Abdallah et al. (2012) & $\mathrm{O}$ & $\mathrm{O}$ & $\mathrm{O}$ & $\mathrm{O}$ & - & - \\
\hline Urata et al. (2017) & $\mathrm{O}$ & $\mathrm{O}$ & - & $\mathrm{O}$ & - & - \\
\hline Cohen and Lee (1989) & $\mathrm{O}$ & $\mathrm{O}$ & $\mathrm{O}$ & $\mathrm{O}$ & - & - \\
\hline Amin and Baki (2017) & $\mathrm{O}$ & $\mathrm{O}$ & $\mathrm{O}$ & - & $\mathrm{O}$ & - \\
\hline Tsiakis and Papageorgiou (2008) & $\mathrm{O}$ & $\mathrm{O}$ & $\mathrm{O}$ & - & $\mathrm{O}$ & - \\
\hline Hosoda et al. (2016) & $\mathrm{O}$ & $\mathrm{O}$ & - & - & $\mathrm{O}$ & - \\
\hline Cohen et al. (1989) & $\mathrm{O}$ & $\mathrm{O}$ & $\mathrm{O}$ & $\mathrm{O}$ & $\mathrm{O}$ & - \\
\hline Vidal and Goetschalckx (2001) & $\mathrm{O}$ & $\mathrm{O}$ & - & $\mathrm{O}$ & 0 & - \\
\hline Arntzen et al. (1995) & 0 & 0 & - & 0 & 0 & - \\
\hline Mariel and Minner (2017) & $\mathrm{O}$ & $\mathrm{O}$ & 0 & $\mathrm{O}$ & 0 & - \\
\hline Nakamura et al. (2016)(2018) & $\mathrm{O}$ & $\mathrm{O}$ & $\mathrm{O}$ & $\mathrm{O}$ & $\mathrm{O}$ & - \\
\hline This study & $\mathrm{O}$ & $\mathrm{O}$ & $\mathrm{O}$ & $\mathrm{O}$ & $\mathrm{O}$ & $\mathrm{O}$ \\
\hline
\end{tabular}

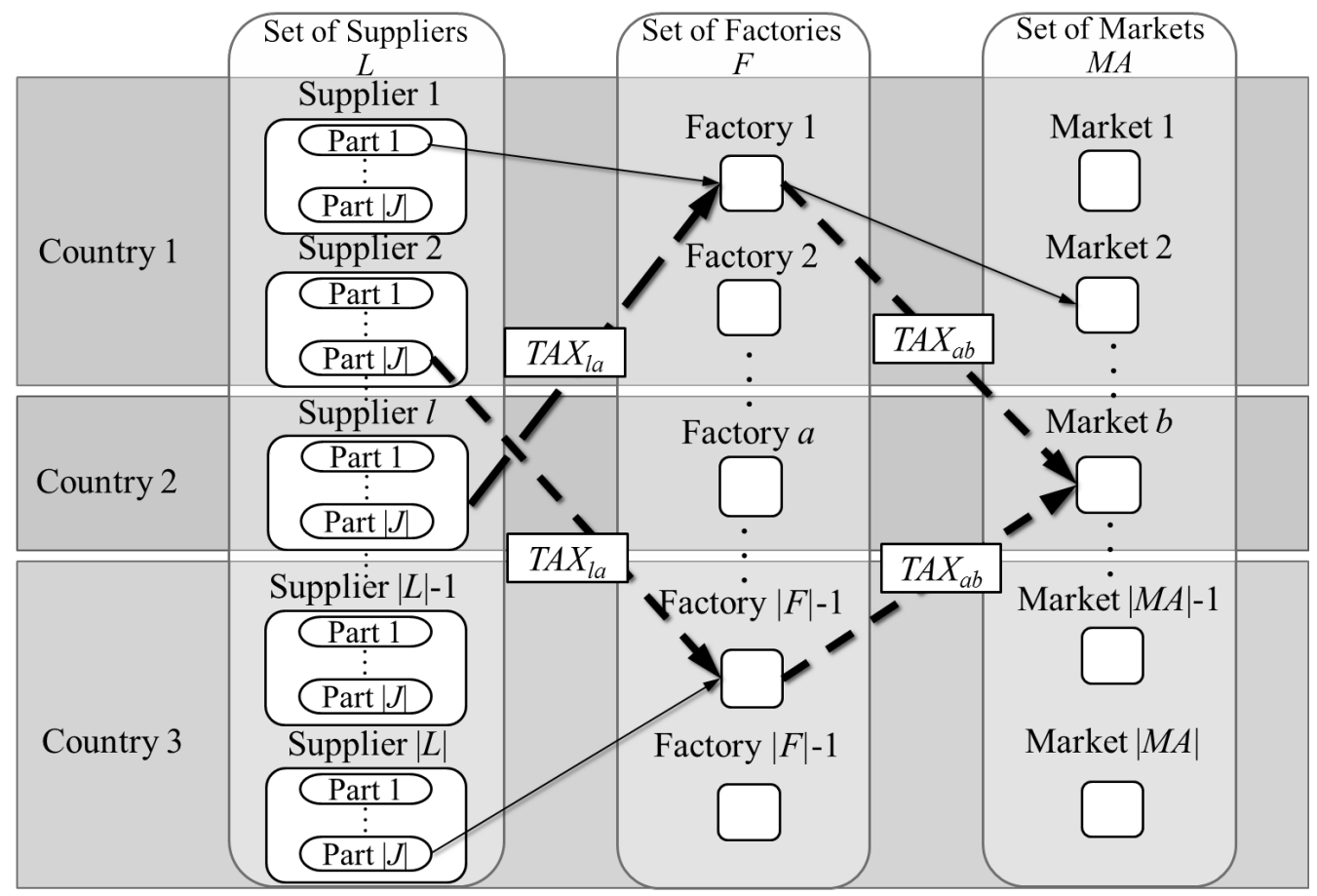

Figure 1: Model of global supply chain with customs duty [20] 


\section{Modeling and Formulation}

\subsection{Notations}

As in [20], this study models the global supply chain network with the customs duty on the assembled products based on [7] [10], as shown in Figure 1. The territories of each country are filled on the figure. First, part $j$ is produced by supplier $l$. Then, the part $j$ is transported by supplier $l$ to factory $a$, which has purchased it. Each product consisting of $n_{j}$ parts is assembled at factory $a$, and after that, these products are transported to market $b$. When international transportation of the parts and products is taking place between suppliers and factories, a customs duty is applied on them.

Notations used in this study are set as follows:

i) Sets

$\begin{array}{ll}L & : \text { Set of suppliers } \\ F & : \text { Set of factories } \\ M A & : \text { Set of markets } \\ J & : \text { Set of parts }\end{array}$

ii) Index

$\begin{array}{lll}l & : & \text { Index of suppliers } \\ a & : & \text { Index of factories } \\ b & : & \text { Index of markets } \\ j & : & \text { Index of parts }\end{array}$

iii) Decision variables
$f_{\text {laj }} \quad: \quad$ Number of parts $j$ transported from supplier $l$ to factory $a$
$f_{a b} \quad: \quad$ Number of products transported from factory $a$ to market $b$
$z_{a b} \quad: \quad 1$, if the route between factory $a$ and market $b$ is open
0 , otherwise
$u_{a} \quad: \quad 1$, if the fixed opening cost at factory $a$ is opened
0 , otherwise

iv) Parameters

$L C_{l a} \quad: \quad$ Transportation cost of parts from supplier $l$ to factory $a$

$L C_{a b} \quad: \quad$ Transportation cost of product from factory $a$ to factory $b$ 


\begin{tabular}{|c|c|c|}
\hline$P C_{l j}$ & : & Procurement cost of part $j$ supplied from supplier $l$ \\
\hline$M C_{a}$ & : & Manufacturing cost of product at factory $a$ \\
\hline$O C_{a b}$ & : & The fixed opening route cost between factory $a$ and market $b$ \\
\hline$F C_{a}$ & : & The fixed factory opening cost at factory $a$ \\
\hline$n_{j}$ & $\cdot$ & Number of parts $j$ needed for a product \\
\hline \multirow[t]{2}{*}{$s_{l j}$} & : & 1 , if supplier $l$ supplies part $j$ \\
\hline & & 0 , otherwise \\
\hline$M$ & $:$ & Very large number \\
\hline$N_{\text {product }, b}$ & $:$ & Number of product units demanded in market $b$ \\
\hline$T A X_{l a}$ & : & Unit customs duty cost on transportation from supplier $l$ to factory $a$ \\
\hline$T A X_{a b}$ & : & Unit customs duty cost on transportation from factory $a$ to market $b$ \\
\hline$\delta(l, a)$ & : & Customs duty rate on the parts transported from supplier $l$ to factory $a$ \\
\hline$\delta(a, b)$ & : & Customs duty rate on the products transported from factory $a$ to market $b$ \\
\hline$d_{l a}$ & : & The distance between supplier $l$ and factory $a$ \\
\hline$d_{a b}$ & $:$ & The distance between factory $a$ and market $b$ \\
\hline$\alpha_{j}$ & : & Coefficient of parts transportation cost \\
\hline$\alpha_{p}$ & : & Coefficient of product transportation cost \\
\hline$Q_{m i n, l a j}$ & : & Minimum order quantity from supplier $l$ and factory $a$ for part $j$ \\
\hline$Q_{m i n, a b}$ & : & Minimum order quantity from factory $a$ to market $b$ for product \\
\hline$Q_{\max , a}$ & & Production capacity at factory $a$ \\
\hline
\end{tabular}

\subsection{Formulation}

The objective function minimizes the sum of the transportation, procurement, customs duty, the fixed opening routes, and factories costs in Eq. (1).

As in [20], the unit transportation cost, $L C_{l a}$, is obtained by multiplying the distance $d_{l a}$ between supplier $l$ and factory $a$ with the transportation cost coefficient $\alpha_{j}$, as shown in Eq. (2). As in Eq. (2), the unit transportation $\cos t L C_{a b}$ is obtained by multiplying the distance $d_{a b}$ between factory $a$ and market $b$ by the cost coefficient of product transportation $\alpha_{p}$, as shown in Eq. (3). The unit customs duty $T A X_{\text {la }}$ is obtained by multiplying the procurement cost of part $j$ supplied by supplier $l$ by the tax rate on the parts transported from supplier $l$ to factory $a$, as shown in Eq. (4). The unit 
customs duty $T A X_{a b}$ is also obtained by multiplying the manufacturing cost of product at factory $a$ by the tax rate on the product transportation from factory $a$ to market $b$, as shown in Eq. (5).

Eq. (6) ensures that the demand of each market is satisfied by the open factory. Eq. (7) sets the condition that the demand for all the parts is met by the assigned suppliers. Eq. (8) ensures that the products are shipped only by the route that is open. Eq. (9) ensures that all products are produced only at the opened factory a under the production capacity $Q_{\max , a}$. Eqs. (10) and (11) enforce the non-negativity and binary restriction. The constraints set in Eqs. (12) to (13) ensure that the transported parts $f_{l a j}$ and products $f_{a b}$ are equal to or over the minimum order quantity $Q_{\text {min, }, a j}$ from supplier $l$ to the factory $a$ for part $j$ and $Q_{\text {min,ab }}$ from the factory $a$ to market $b$ for products, respectively.

The objective function is given by:

$$
\begin{aligned}
& \sum_{l \in L} \sum_{a \in F} \sum_{j \in J}\left(L C_{l a}+P C_{l j}+T A X_{l a}\right) f_{l a j}+\sum_{a \in F} \sum_{b \in M A}\left(L C_{a b}+M C_{a}+T A X_{a b}\right) f_{a b} \\
& +\sum_{a \in F} \sum_{b \in M A} O C_{a b} z_{a b}+\sum_{a \in F} F C_{a} u_{a} \rightarrow \min \\
& L C_{l a}=d_{l a} \times \alpha_{j} \\
& L C_{a b}=d_{a b} \times \alpha_{p} \\
& T A X_{l a}=P C_{l j} \times \delta(l, a) \\
& T A X_{a b}=M C_{a} \times \delta(a, b)
\end{aligned}
$$

Constraints:

$$
\begin{aligned}
& \sum_{a \in F} f_{a b}=\quad N_{\text {product }, b} \quad \forall b \in M A \\
& \sum_{l \in L} s_{l j} f_{l a j}=\sum_{b \in M A} f_{a b} n_{j} \quad \forall a \in F, \forall j \in J \\
& f_{a b} \leq M z_{a b} \quad \forall a \in F, \forall b \in M A \\
& \sum_{b \in M A} f_{a b} \leq Q_{\max , a} u_{a} \quad \forall a \in F \\
& f_{l a j}, f_{a b} \geq 0 \quad \forall l \in L, \forall a \in F, \forall b \in M A, \forall j \in J \\
& z_{a b}, u_{a}=\{1,0\} \quad \forall a \in F, \forall b \in M A \\
& f_{l a j} \geq Q_{\min , l a j} \quad \forall l \in L, \forall a \in F, \forall j \in J
\end{aligned}
$$


$f_{a b} \geq Q_{\min , a b} \quad \forall a \in F, \forall b \in M A$

\section{An Example Problem of Global Supply Chain Network with TPP}

\subsection{Assumptions}

In order to solve the mixed integer programing (MIP) problem formulated with Eqs. (1) - (11), this study uses the example of a vacuum cleaner using a 3D-CAD model [22] and the BOM as well as [10]. Table 2 shows the BOM identifying parts name, material name, supplier location, number of parts, weights of each part, and the procurement cost of parts. By using the BOM, it is possible to analyze considering the type of material. Furthermore, this study analyzes the influence of fluctuating material prices on a global supply chain network under TPP. As it is a global supply chain problem, China, Japan and Malaysia are chosen. This is because the gross domestic products (GDPs) of China and Japan are among the highest in the world next to the United States, and Malaysia is the country with the shortest distance to Japan among the TPP member countries. The assumptions relating to the examples used in the problem and the TPP are set as follows:

- The city to which the products will be shipped is Tokyo, and 1,000 units of the product will be sent.

- The factory locations and distances between the suppliers and the factories are based on the distances between cities and towns in Japan, China, and Malaysia in [10].

- Minimum order quantities: $Q_{\min , l a j}=0$ and $Q_{\min , a b}=0$.

- Production capacity at factory $a: Q_{\max , a}=10,000$.

- In order to clarify the influence of TPP and material price fluctuation on the supply chain network, this study do not consider the influence of the exchange rate.

- The motor is always procured from China as well as [10]. This is because the procurement cost of the motor is about $95 \%$ of the total cost of procurement of all the parts.

In addition, in order to examine effects of TPP on the global supply chain network, this study prepares two scenarios related to customs duty rates for the TPP.

- Scenario A: Without TPP

When the international transportation of parts and product occurs, this scenario sets the customs duty rate for parts and products $a s \delta(l, a)$ and $\delta(a, b)$, respectively.

- Scenario B: With TPP

When the international transportation is between Japan and Malaysia, this scenario sets the customs duty rate as $0 \%$ because both countries are signatories to the TPP and incur no customs duty cost. 
The solution and related results are calculated on a personal computer with Windows 7, Intel ${ }^{\circledR}$ CoreTM 17-2600 CPU operating at 3.40GHz, and a commercially available optimization solver, Numerical Optimizer, provided by NTT DATA Mathematical Systems Inc. [23].

Table 2: Bill of materials for procurement costs in the case of a vacuum cleaner (Urata et al., [10]).

\begin{tabular}{|c|c|c|c|c|c|c|c|c|c|c|}
\hline \multirow{2}{*}{$\begin{array}{l}\text { Part } \\
\text { No. }\end{array}$} & \multirow{2}{*}{ Part name } & \multirow{2}{*}{ Material name } & \multirow{2}{*}{$\begin{array}{l}\text { Malaysian } \\
\text { supplier }\end{array}$} & \multirow{2}{*}{$\begin{array}{l}\text { Chinese } \\
\text { suppliers }\end{array}$} & \multirow{2}{*}{$\begin{array}{l}\text { Japanese } \\
\text { suppliers }\end{array}$} & \multirow{2}{*}{$\begin{array}{l}\text { Number of } \\
\text { parts }\end{array}$} & \multirow{2}{*}{ Weight $[\mathrm{g}]$} & \multicolumn{3}{|c|}{ Procurement cost [US\$] } \\
\hline & & & & & & & & Malaysia & China & Japan \\
\hline 1 & Wheel of nozzle & Polypropylen & Alor Star & Guangzhou & Fukuoka & 2 & 7.07 & 0.0108 & 0.0098 & 0.0196 \\
\hline 2 & Wheel stopper & Polypropylen & Penang & Chongqing & Hiroshima & 2 & 1.71 & 0.0026 & 0.0024 & 0.0047 \\
\hline 3 & Upper nozzle & Polypropylen & Kuantan & Nanjin & Yokohama & 1 & 50.35 & 0.0384 & 0.0349 & 0.0698 \\
\hline 4 & Lower nozzle & Polypropylen & malacca & Harbin & Osaka & 1 & 41.25 & 0.0314 & 0.0286 & 0.0572 \\
\hline 5 & Nozzle & Polypropylen & Kuala Lumpur & Xian & Nagoya & 1 & 34.50 & 0.0263 & 0.0239 & 0.0478 \\
\hline 6 & Right handle & Polypropylen & Johor Bahru & Chengdu & Sapporo & 1 & 48.93 & 0.0373 & 0.0339 & 0.0678 \\
\hline 7 & Switch & Polyvinyl chloride & Kuching & Changchun & Kumamoto & 1 & 4.65 & 0.0032 & 0.0029 & 0.0058 \\
\hline 8 & Left handle & Polypropylen & Sibu & Dalian & Kobe & 1 & 51.70 & 0.0394 & 0.0358 & 0.0716 \\
\hline 9 & Left body & Polypropylen & Miri & Hangzhou & Shizuoka & 1 & 187.27 & 0.1427 & 0.1298 & 0.2595 \\
\hline 10 & Right body & Polypropylen & Kota Kinabalu & Jinan & Kyoto & 1 & 179.88 & 0.1371 & 0.1246 & 0.2493 \\
\hline 11 & Dust case cover & Methacrylate resin & Sandakan & Qingdao & Sendai & 1 & 36.57 & 0.0530 & 0.0482 & 0.0964 \\
\hline 12 & Mesh filter & Carbon fiber & Ipoh & Suzhou & Niigata & 1 & 18.45 & 0.3294 & 0.2995 & 0.5990 \\
\hline 13 & Connection pipe & Aluminum alloy & Penang & Fuzhou & Wakayama & 1 & 47.17 & 0.0556 & 0.0506 & 0.1012 \\
\hline 14 & Dust case & Methacrylate resin & Alor Star & Nanjin & Hiroshima & 1 & 175.69 & 0.2548 & 0.2316 & 0.4632 \\
\hline 15 & Exhaust tube & Polyvinyl chloride & Kuala Lumpur & Guangzhou & Kumamoto & 1 & 32.04 & 0.0221 & 0.0201 & 0.0401 \\
\hline 16 & Upper filter & Carbon fiber & Penang & Hangzhou & Niigata & 1 & 17.74 & 0.3168 & 0.2880 & 0.5759 \\
\hline 17 & Lower filter & Polypropylen & Kota Kinabalu & Xian & Wakayama & 1 & 29.33 & 0.0224 & 0.0203 & 0.0406 \\
\hline 18 & Protection cap & Polystyrene (ABS) & Alor Star & Jinan & Kobe & 1 & 22.29 & 0.0240 & 0.0218 & 0.0437 \\
\hline 19 & Motor & DC motors & - & - & - & 1 & 279.27 & 61.6491 & 56.0447 & 112.0893 \\
\hline 20 & $\begin{array}{l}\text { Rubber of outer } \\
\text { flame of fan }\end{array}$ & Synthetic rubber & Sibu & Qingdao & Sapporo & 1 & 22.85 & 0.0306 & 0.0278 & 0.0556 \\
\hline 21 & Outer flame of fan & Aluminum alloy & Ipoh & Dalian & Sendai & 1 & 55.11 & 0.0650 & 0.0591 & 0.1182 \\
\hline 22 & Lower fan & Polypropylen & Kuching & Chongqing & Yokohama & 1 & 15.08 & 0.0115 & 0.0104 & 0.0209 \\
\hline \multirow[t]{4}{*}{23} & Fan & Aluminum alloy & Kuantan & Chengdu & Nagoya & 1 & 62.10 & 0.0732 & 0.0666 & 0.1332 \\
\hline & Total & & & & & 25 & 1421.00 & 63.38 & 57.62 & 115.23 \\
\hline & Average & & & & & 1.09 & 61.78 & 2.76 & 2.51 & 5.01 \\
\hline & tandard deviation & & & & & 0.28 & 71.77 & 12.84 & 11.42 & 22.83 \\
\hline
\end{tabular}




\section{Results of the Redesign Problem When Prices of Materials fluctuate}

\subsection{Assumptions}

The recent fluctuations in material and energy prices in the business world affect the global supply chain network. For example, an increment in oil prices causes an increment in the unit cost of material such as plastics. Furthermore, an increment in oil prices, it may also lead to the switching of suppliers. Therefore, this study simulates two cases with different prices of polypropylene, which is derived from oil. It is assumed that the material cost of the other parts are not changed. In the baseline case, the customs duty rate on parts and product is $20 \%$ while the price of polypropylene does not increase.

It is often expensive to open a new factory overseas. This section considers the redesign problem, where in a factory is already operating in Japan, and a relocation to one of the overseas factories is considered.

- The factory opening cost $F C_{a}$ in Japan is set as US\$ 0 .

- The factory opening costs $F C_{a}$ in China and Malaysia are set as US\$ 5,000 and US\$ 5,400, respectively.

\subsection{Results of Suppliers and Factory Locations Selected When Oil Prices Change}

\section{(1) With TPP}

Table 3 shows total cost and its breakdown when prices of polypropylene fluctuate with TPP. When the unit price of polypropylene is double that of the baseline price, the total cost becomes by $6.6 \%$ higher than the baseline cost. On the other hand, when the unit price of polypropylene is half the baseline price, the total cost becomes by $4.4 \%$ lower than the baseline. In this section, the factory is always opened in Japan. Table 4 shows the results of the suppliers and the factory locations selection when the prices of polypropylene fluctuate. From table 4, we find that when the unit price of polypropylene is double the baseline price, the Chinese suppliers for two of the parts- \#9 Left body and \#10 Right body—are replaced by the Malaysian suppliers. These parts are among the heaviest of all the parts made of polypropylene. As the cost of polypropylene increases, the costs of the heavier polypropylene parts would be affected more. Therefore, the Malaysian suppliers are selected to reduce the cost of customs duty. Similarly, for \#5 Nozzle and \#17 Lower filter, there is a switch from the Japanese to the Chinese suppliers.

On the other hand, when the unit cost of polypropylene is half the baseline cost, a switch from the Chinese to the Japanese suppliers occurs for \#3 Upper nozzle, \#4 Lower nozzle, and \#6 Right handle. The weights of these parts are the lightest among the parts transported from the Chinese supplier. With regard to the lighter parts, the ratio of their transportation cost in the total cost becomes very high. Therefore, the Japanese suppliers are selected to reduce transportation cost. 
Table 3: Total cost and its breakdown when prices of polypropylene fluctuate with TPP

\begin{tabular}{|l||r|r||r||r|r|}
\hline \multicolumn{1}{|c||}{ Scenario name } & $\begin{array}{c}\text { Unit price of } \\
\text { polypropylene } \\
\text { halved }\end{array}$ & $\begin{array}{c}\text { Increment from } \\
\text { the baseline [\%] }\end{array}$ & $\begin{array}{c}\text { Baseline } \\
\text { (Rate of customs } \\
\text { duty on parts and } \\
\text { product is 20\%) }\end{array}$ & $\begin{array}{c}\text { Unit price of } \\
\text { polypropylene } \\
\text { doubled }\end{array}$ & $\begin{array}{c}\text { Increment from } \\
\text { the baseline [\%] }\end{array}$ \\
\hline \hline Total transportation cost of parts & 308.9 & $-15.4 \%$ & 365.3 & 459.4 & $25.8 \%$ \\
\hline Total procurement cost of parts & 1431.1 & $-15.1 \%$ & 1684.8 & 2192.8 & $30.2 \%$ \\
\hline Total customs duty on parts & 241.8 & $-18.4 \%$ & 296.2 & 289.6 & $-2.2 \%$ \\
\hline Total transportation cost of products & 0.1 & $0 \%$ & 0.1 & 0.1 & $0 \%$ \\
\hline Total customs duty on products & 0.0 & - & 0.0 & 0.0 & - \\
\hline $\begin{array}{l}\text { The opening route cost } \\
\text { between factory and market }\end{array}$ & 50.0 & $0 \%$ & 50.0 & 50.0 & $0 \%$ \\
\hline The opening factory cost & 0.0 & - & 0.0 & 0.0 & - \\
\hline Total manufacturing cost of product & 6666.7 & $0 \%$ & 6666.7 & 6666.7 & $0 \%$ \\
\hline \hline Total cost & 8698.5 & $-4.0 \%$ & 9063.0 & 9658.6 & $6.6 \%$ \\
\hline
\end{tabular}

Table 4: Suppliers and factory locations selected when prices of polypropylene fluctuate with TPP

\begin{tabular}{|c|c|c|c|c|c|c|c|c|c|}
\hline & & & & & & & $\begin{array}{l}\text { Unit price of } \\
\text { polypropylene } \\
\text { halved }\end{array}$ & $\begin{array}{l}\text { Baseline } \\
\text { (Rate of } \\
\text { customs duty } \\
\text { on parts and } \\
\text { product is } \\
20 \% \text { ) }\end{array}$ & $\begin{array}{l}\text { Unit price of } \\
\text { polypropylene } \\
\text { doubled }\end{array}$ \\
\hline Part No & Part name & Material name & $\begin{array}{c}\text { Number of } \\
\text { parts }\end{array}$ & Weight $[\mathrm{g}]$ & $\begin{array}{c}\text { Material } \\
\text { cost } \\
{[\mathrm{US} \$ / \mathrm{g}]}\end{array}$ & \begin{tabular}{|c|} 
Parts \\
procureme \\
nt cost \\
[US\$]
\end{tabular} & Supplier & Supplier & Supplier \\
\hline 1 & Wheel of nozzle & Polypropylene & 2 & 7.07 & 0.0014 & 0.0196 & Fukuoka & Fukuoka & Fukuoka \\
\hline 2 & Wheel stopper & Polypropylene & 2 & 1.71 & 0.0014 & 0.0047 & Hiroshima & Hiroshima & Hiroshima \\
\hline 3 & Upper nozzle & Polypropylene & 1 & 50.35 & 0.0014 & 0.0698 & Yokohama & Nanin & Mangin \\
\hline 4 & Lower nozzle & Polypropylene & 1 & 41.25 & 0.0014 & 0.0572 & Osaka & Halon & Mancila \\
\hline 5 & Nozzle & Polypropylene & 1 & 34.5 & 0.0014 & 0.0478 & Nagoya & Nagoya & Nial \\
\hline 6 & Right handle & Polypropylene & 1 & 48.93 & 0.0014 & 0.0678 & Sapporo & Obectodu & Obeigdu \\
\hline 7 & Switch & Polyvinyl chloride & 1 & 4.65 & 0.0013 & 0.0058 & Kumamoto & Kumamoto & Kumamoto \\
\hline 8 & Left handle & Polypropyle ne & 1 & 51.7 & 0.0014 & 0.0716 & Nantan & Nollom & Nollan: \\
\hline 9 & Left body & Polypropyle ne & 1 & 187.27 & 0.0014 & 0.2595 & Alinghous & Hans on & Mill \\
\hline 10 & Right body & Polypropylene & 1 & 179.88 & 0.0014 & 0.2493 & $\operatorname{ligan}$ & $\operatorname{linan}$ & Kota K n b o n \\
\hline 11 & Dust case cover & Methacrylate resin & 1 & 36.57 & 0.0026 & 0.0964 & Qingdaro & Quinda. & Quindalo \\
\hline 12 & Mesh filter & Carbon fiber & 1 & 18.45 & 0.0325 & 0.5990 & Surnout & SNode & Swom \\
\hline 13 & Connection pipe & Aluminum alloy & 1 & 47.17 & 0.0021 & 0.1012 & Inoges & Whou & ind \\
\hline 14 & Dust case & Methacrylate resin & 1 & 175.69 & 0.0026 & 0.4632 & $M$ & Wanto & Whing \\
\hline 15 & Exhaust tube & Polyvinyl chloride & 1 & 32.04 & 0.0013 & 0.0401 & Kumamoto & Kumamoto & Kumamoto \\
\hline 16 & Upper filter & Carbon fiber & 1 & 17.74 & 0.0325 & 0.5759 & Hongsom & Hang $x$ det & Along \\
\hline 17 & Lower filter & Polypropyle ne & 1 & 29.33 & 0.0014 & 0.0406 & Wakayama & Wakayama & Wial \\
\hline 18 & Protection cap & Polystyrene (ABS) & 1 & 22.29 & 0.0020 & 0.0437 & Whan & Mhan & Hinan \\
\hline 20 & $\begin{array}{l}\text { Rubber of outer } \\
\text { flame of fan }\end{array}$ & Synthetic rubber & 1 & 22.85 & 0.0024 & 0.0556 & Qingdao & Oringda- & oringas \\
\hline 21 & Outer flame of fan & Aluminum alloy & 1 & 55.11 & 0.0021 & 0.1182 & 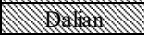 & 1112 & Hoinin \\
\hline 22 & Lower fan & Polypropylene & 1 & 15.08 & 0.0014 & 0.0209 & Yokohama & Yokohama & Yokohama \\
\hline 23 & Fan & Aluminum alloy & 1 & 62.1 & 0.0021 & 0.1332 & Cheming & Chengu & d ndu \\
\hline \multicolumn{3}{|c|}{ Total } & 25 & 1421 & & & & & \\
\hline \multicolumn{3}{|c|}{ Average } & 1.09 & 61.78 & 0.0045 & 0.1428 & & & \\
\hline \multicolumn{7}{|c|}{ Explanatory notes: } & Japan & Nonges & $\mathrm{Na} / \mathrm{a} \times \mathrm{o}$ \\
\hline
\end{tabular}


In this study, the part procurement cost is obtained by multiplying the material cost of the part by its weight [24]. Moreover, the parts with higher costs have either higher material cost or weights. Therefore, suppliers of these parts switch to lower cost suppliers. On the other hand, the parts with lower costs have lower material costs and weights. Therefore, suppliers of these parts switch to suppliers closer to the factory in order to reduce transportation cost.

\section{(2) Without TPP}

From now, the results of the supplier and factory locations selection are compared with TPP and without TPP. Table 5 shows that when the unit price of polypropylene is double that of the baseline price without TPP, the total cost becomes by $6.6 \%$ higher than the baseline cost. On the other hand, when the unit price of polypropylene is half the baseline price without TPP, the total cost becomes by $4.4 \%$ lower than the baseline. Table 7 shows total cost and its breakdown when prices of polypropylene doubled with TPP and without TPP. There is a $0.1 \%$ difference in total cost by TPP.

Table 6 shows suppliers and factory locations selected when prices of polypropylene fluctuate without TPP. When the unit price of polypropylene is double the baseline, with TPP, the Chinese suppliers for two of the parts-\#9 Left body and \#10 Right body—are replaced by the Malaysian suppliers (Table 4). However, these suppliers were not replaced without TPP.

In the case with TPP, the customs duty cost of parts is applied only to the Chinese supplier. Therefore, when the material prices fluctuated, only the price of the Chinese supplier parts increased by the customs duty. Malaysian suppliers are selected to reduce customs duty on parts. On the other hand, in the case without TPP, the same customs duty rate is applied on both China and Malaysia. The effect of fluctuations in material prices is greater for Malaysian suppliers with higher procurement costs than for Chinese suppliers. Therefore, without TPP, not Malaysian suppliers but Chinese suppliers are selected to reduce transportation cost of parts.

Table 5: Total cost and its breakdown when prices of polypropylene fluctuate without TPP

\begin{tabular}{|c|c|c|c|c|c|}
\hline Scenario name & $\begin{array}{c}\text { Unit price of } \\
\text { polypropylene } \\
\text { halved }\end{array}$ & $\begin{array}{l}\text { Increment from } \\
\text { the baseline }[\%]\end{array}$ & \begin{tabular}{||c||} 
Baseline \\
(Rate of customs \\
duty on parts and \\
product is $20 \%$ ) \\
\end{tabular} & $\begin{array}{c}\text { Unit price of } \\
\text { polypropylene } \\
\text { doubled }\end{array}$ & $\begin{array}{l}\text { Increment from } \\
\text { the baseline }[\%]\end{array}$ \\
\hline Total transportation cost of parts & 308.9 & $-15.4 \%$ & 365.3 & $\overline{4} 414.2$ & $13.4 \%$ \\
\hline Total procurement cost of parts & 1431.1 & $-15.1 \%$ & 1684.8 & 2141.9 & $27.1 \%$ \\
\hline Total customs duty on parts & 241.8 & $-18.4 \%$ & 296.2 & 391.4 & $32.1 \%$ \\
\hline Total transportation cost of products & 0.1 & $0 \%$ & 0.1 & 0.1 & $0 \%$ \\
\hline Total customs duty on products & 0.0 & - & 0.0 & 0.0 & - \\
\hline $\begin{array}{l}\text { The opening route cost } \\
\text { between factory and market }\end{array}$ & 50.0 & $0 \%$ & 50.0 & 50.0 & $0 \%$ \\
\hline The opening factory cost & 0.0 & - & 0.0 & 0.0 & - \\
\hline Total manufacturing cost of product & 6666.7 & $0 \%$ & 6666.7 & 6666.7 & $0.0 \%$ \\
\hline Total cost & 8698.5 & $-4.0 \%$ & 9063.0 & 9664.3 & $6.6 \%$ \\
\hline
\end{tabular}


Table 6: Suppliers and factory locations selected when prices of polypropylene fluctuate without TPP

\begin{tabular}{|c|c|c|c|c|c|c|c|c|c|}
\hline & & & & & & & $\begin{array}{c}\text { Unit price of } \\
\text { polypropylene } \\
\text { halved }\end{array}$ & $\begin{array}{l}\text { Baseline } \\
\text { (Rate of } \\
\text { customs duty } \\
\text { on parts and } \\
\text { product is } \\
20 \% \text { ) }\end{array}$ & $\begin{array}{c}\text { Unit price of } \\
\text { polypropylene } \\
\text { doubled }\end{array}$ \\
\hline Part No & Part name & Material name & $\begin{array}{c}\text { Number of } \\
\text { parts }\end{array}$ & Weight $[\mathrm{g}]$ & $\begin{array}{c}\text { Material } \\
\text { cost } \\
\text { [US\$ } / \mathrm{g}]\end{array}$ & $\begin{array}{c}\text { Parts } \\
\text { procureme } \\
\text { nt cost } \\
\text { [US\$] }\end{array}$ & Supplier & Supplier & Supplier \\
\hline 1 & Wheel of nozzle & Polypropylene & 2 & 7.07 & 0.0014 & 0.0196 & Fukuoka & Fukuoka & Fukuoka \\
\hline 2 & Wheel stopper & Polypropylene & 2 & 1.71 & 0.0014 & 0.0047 & Hiroshima & Hiroshima & Hiroshima \\
\hline 3 & Upper nozzle & Polypropyle ne & 1 & 50.35 & 0.0014 & 0.0698 & Yokohama & Narions & Nanim \\
\hline 4 & Lower nozzle & Polypropylene & 1 & 41.25 & 0.0014 & 0.0572 & Osaka & Hand & Hanom \\
\hline 5 & Nozzle & Polypropylene & 1 & 34.5 & 0.0014 & 0.0478 & Nagoya & Nagoya & Cani \\
\hline 6 & Right handle & Polypropylene & 1 & 48.93 & 0.0014 & 0.0678 & Sapporo & Wendu & Chengin \\
\hline 7 & Switch & Polyvinyl chloride & 1 & 4.65 & 0.0013 & 0.0058 & Kumamoto & Kumamoto & Kumamoto \\
\hline 8 & Left handle & Polypropylene & 1 & 51.7 & 0.0014 & 0.0716 & Dalan: & Dallan & Ballan: \\
\hline 9 & Left body & Polypropylene & 1 & 187.27 & 0.0014 & 0.2595 & 1.angenos & $12 \log$ & Hang $/ 404$ \\
\hline 10 & Right body & Polypropylene & 1 & 179.88 & 0.0014 & 0.2493 & 1 & +1 & $1-1$ \\
\hline 11 & Dust case cover & Methacrylate resin & 1 & 36.57 & 0.0026 & 0.0964 & Qingcar & Qingdito. & Qunda. \\
\hline 12 & Mesh filter & Carbon fiber & 1 & 18.45 & 0.0325 & 0.5990 & Swan & Sundone & Singou \\
\hline 13 & Connection pipe & Aluminum alloy & 1 & 47.17 & 0.0021 & 0.1012 & 7000 & Noin & 1000 \\
\hline 14 & Dust case & Methacrylate resin & 1 & 175.69 & 0.0026 & 0.4632 & Noin: & Naning & Mangm \\
\hline 15 & Exhaust tube & Polyvinyl chloride & 1 & 32.04 & 0.0013 & 0.0401 & Kumamoto & Kumamoto & Kumamoto \\
\hline 16 & Upper filter & Carbon fiber & 1 & 17.74 & 0.0325 & 0.5759 & Hanghage & Hang & Hand \\
\hline 17 & Lower filter & Polypropylene & 1 & 29.33 & 0.0014 & 0.0406 & Wakayama & Wakayama & (1)ini: \\
\hline 18 & Protection cap & Polystyrene (ABS) & 1 & 22.29 & 0.0020 & 0.0437 & Hinan & Winan & Tinan \\
\hline 20 & $\begin{array}{l}\text { Rubber of outer } \\
\text { flame of fan }\end{array}$ & Synthetic rubber & 1 & 22.85 & 0.0024 & 0.0556 & Qingda & (inged o & Anges \\
\hline 21 & Outer flame of fan & Aluminum alloy & 1 & 55.11 & 0.0021 & 0.1182 & Ditan & Dalan. & Aallan \\
\hline 22 & Lower fan & Polypropylene & 1 & 15.08 & 0.0014 & 0.0209 & Yokohama & Yokohama & Yokohama \\
\hline 23 & Fan & Aluminum alloy & 1 & 62.1 & 0.0021 & 0.1332 & Ahemodt & Chendgin & Chensides \\
\hline \multicolumn{3}{|c|}{ Total } & 25 & 1421 & & & & & \\
\hline \multicolumn{3}{|c|}{ Average } & 1.09 & 61.78 & 0.0045 & 0.1428 & & & \\
\hline \multicolumn{7}{|c|}{ Explanatory notes: } & Japan & olinas & Mays \\
\hline
\end{tabular}

Table 7: Total cost and its breakdown when prices of polypropylene doubled with TPP and without TPP

\begin{tabular}{|l||r||r|r|}
\hline Scenario name & $\begin{array}{c}\text { Scenario A } \\
\text { without TPP } \\
\text { Unit price of } \\
\text { polypropylene } \\
\text { doubled }\end{array}$ & $\begin{array}{c}\text { Scenario B } \\
\text { with TPP } \\
\text { Unit price of } \\
\text { polypropylene } \\
\text { doubled }\end{array}$ & $\begin{array}{c}\text { Increment from } \\
\text { the Scenario A } \\
{[\%]}\end{array}$ \\
\hline \hline Total transportation cost of parts & 414.2 & 459.4 & $10.9 \%$ \\
\hline Total procurement cost of parts & 2141.9 & 2192.8 & $2.4 \%$ \\
\hline Total customs duty on parts & 391.4 & 289.6 & $-26.0 \%$ \\
\hline Total transportation cost of products & 0.1 & 0.1 & $0 \%$ \\
\hline Total customs duty on products & 0.0 & 0.0 & - \\
\hline $\begin{array}{l}\text { The opening route cost } \\
\text { between factory and market }\end{array}$ & 50.0 & 50.0 & $0 \%$ \\
\hline The opening factory cost & 0.0 & 0.0 & - \\
\hline Total manufacturing cost of product & 6666.7 & 6666.7 & $0 \%$ \\
\hline \hline Total cost & 9664.3 & 9658.6 & $-0.1 \%$ \\
\hline
\end{tabular}




\subsection{Results of suppliers and factory locations selected when the prices of the aluminum alloy fluctuates}

\section{(1) With TPP}

This chapter shows that when material prices fluctuate, total cost due to supplier selection with TPP is less susceptible than without TPP. In this case, the experiment is conducted when fluctuates the prices of aluminum alloy to compare the results with those obtained when the price of polypropylene fluctuates. A sensitivity analysis of the aluminum alloy prices is conducted, whereas the other factors which affect the part procurement cost, such as the number of parts and their weight, are treated as fixed in the experiments.

Table 8 shows total cost and its breakdown when prices of aluminum alloy fluctuate with TPP. When the unit price of the aluminum alloy becomes double the baseline price, the total cost is by $2.3 \%$ higher than the baseline cost. On the other hand, when the unit price of aluminum alloy is decreased to half the baseline price, the total cost is by $1.2 \%$ less than the baseline cost. From table 9, when the unit cost of aluminum alloy double that of the baseline cost, there is no change in the choice of supplier. However, when the unit cost of aluminum alloy is half the baseline cost, only the part \#23 Fan is sourced from the Chinese supplier instead of the Japanese one. One of the reasons is that this is the heaviest among all the parts of the aluminum alloy. It is noted that this result is different from the results obtained due to the fluctuation in polypropylene prices. The results can be explained by focusing on the location of the city, Chengdu city, where the Chinese supplier of part \#23 is located. As it is inland, the transportation cost of this part to the factory is higher than that incurred when it is supplied from other Japanese and Chinese suppliers. Therefore, to reduce the transportation cost, the Japanese supplier is preferred over the Chinese supplier at Chengdu city.

\section{(2) Without TPP}

When prices of aluminum alloy fluctuate without TPP, the result has the same total cost and supplier selection with TPP. Malaysia suppliers are not selected when the aluminum alloy price fluctuated with TPP. Therefore, it does not change the total cost and supplier selection because suppliers affected by TPP were not selected.

Table 8: Total cost and its breakdown when prices of aluminum alloy fluctuate with TPP

\begin{tabular}{|c|c|c|c|c|c|}
\hline Scenario name & \begin{tabular}{||c} 
Unit price of \\
Aluminum alloy \\
halved
\end{tabular} & $\begin{array}{l}\text { Increment from } \\
\text { the baseline [\%] }\end{array}$ & $\begin{array}{c}\text { Baseline } \\
\text { (Rate of customs } \\
\text { duty on parts and } \\
\text { product is } 20 \% \text { ) }\end{array}$ & \begin{tabular}{||c} 
Unit price of \\
Aluminum \\
alloy doubled
\end{tabular} & $\begin{array}{l}\text { Increment from } \\
\text { the baseline }[\%]\end{array}$ \\
\hline Total transportation cost of parts & 334.4 & $-8.5 \%$ & 365.3 & 365.3 & $0 \%$ \\
\hline Total procurement cost of parts & 1629.9 & $-3.3 \%$ & 1684.8 & 1861.0 & $10.5 \%$ \\
\hline Total customs duty on parts & 271.9 & $-8.2 \%$ & 296.2 & 331.4 & $11.9 \%$ \\
\hline Total transportation cost of products & 0.1 & $0 \%$ & 0.1 & 0.1 & $0 \%$ \\
\hline Total customs duty on products & 0.0 & - & 0.0 & 0.0 & - \\
\hline $\begin{array}{l}\text { The opening route cost } \\
\text { between factory and market }\end{array}$ & 50.0 & $0 \%$ & 50.0 & 50.0 & $0 \%$ \\
\hline The opening factory cost & 0.0 & - & 0.0 & 0.0 & - \\
\hline Total manufacturing cost of product & 6666.7 & $0 \%$ & 6666.7 & 6666.7 & $0 \%$ \\
\hline Total cost & 8952.9 & $-1.2 \%$ & 9063.0 & 9274.5 & $2.3 \%$ \\
\hline
\end{tabular}


Table 9: Suppliers and factory locations selected when prices of aluminum alloy fluctuate with TPP

\begin{tabular}{|c|c|c|c|c|c|c|c|c|c|}
\hline & & & & & & & $\begin{array}{l}\text { Unit price of } \\
\text { Aluminum } \\
\text { alloy halved }\end{array}$ & $\begin{array}{c}\text { Baseline } \\
\text { (Rate of } \\
\text { customs duty } \\
\text { on parts and } \\
\text { product is } \\
20 \% \text { ) }\end{array}$ & $\begin{array}{l}\text { Unit price of } \\
\text { Aluminum } \\
\text { alloy doubled }\end{array}$ \\
\hline Part No & Part name & Material name & $\begin{array}{c}\text { Number of } \\
\text { parts }\end{array}$ & Weight $[\mathrm{g}]$ & $\begin{array}{c}\text { Material } \\
\text { cost } \\
{[\mathrm{US} \$ \mathrm{~g}]}\end{array}$ & \begin{tabular}{|c|} 
Parts \\
procureme \\
nt cost \\
[US\$]
\end{tabular} & Supplier & Supplier & Supplier \\
\hline 1 & Wheel of nozzle & Polypropylene & 2 & 7.07 & 0.0014 & 0.0196 & Fukuoka & Fukuoka & Fukuoka \\
\hline 2 & Wheel stopper & Polypropylene & 2 & 1.71 & 0.0014 & 0.0047 & Hiroshima & Hiroshima & Hiroshima \\
\hline 3 & Upper nozzle & Polypropylene & 1 & 50.35 & 0.0014 & 0.0698 & Mainu & W & WName \\
\hline 4 & Lower nozzle & Polypropylene & 1 & 41.25 & 0.0014 & 0.0572 & Nanthe & Manbina & Marbin \\
\hline 5 & Nozzle & Polypropylene & 1 & 34.5 & 0.0014 & 0.0478 & Nagoya & Nagoya & Nagoya \\
\hline 6 & Right handle & Polypropylene & 1 & 48.93 & 0.0014 & 0.0678 & Chengdu & Chendu & Rengal \\
\hline 7 & Switch & Polyvinyl chloride & 1 & 4.65 & 0.0013 & 0.0058 & Kumamoto & Kumamoto & Kumamoto \\
\hline 8 & Left handle & Polypropylen & 1 & 51.7 & 0.0014 & 0.0716 & Marian. & Han & Hallan: \\
\hline 9 & Left body & Polypropylen & 1 & 187.27 & 0.0014 & 0.2595 & Haing & Hangoul & Hanosou \\
\hline 10 & Right body & Polypropylen & 1 & 179.88 & 0.0014 & 0.2493 & Inain & Minan & Giran \\
\hline 11 & Dust case cover & Methacrylate resin & 1 & 36.57 & 0.0026 & 0.0964 & Oimgdar & Qinda & Qingado \\
\hline 12 & Mesh filter & Carbon fiber & 1 & 18.45 & 0.0325 & 0.5990 & SH: & 1004 & 5 \\
\hline 13 & Connection pipe & Aluminum alloy & 1 & 47.17 & 0.0021 & 0.1012 & Nod & Nou & Nou \\
\hline 14 & Dust case & Methacrylate resin & 1 & 175.69 & 0.0026 & 0.4632 & W & 19ism & (1) \\
\hline 15 & Exhaust tube & Polyvinyl chloride & 1 & 32.04 & 0.0013 & 0.0401 & Kumamoto & Kumamoto & Kumamoto \\
\hline 16 & Upper filter & Carbon fiber & 1 & 17.74 & 0.0325 & 0.5759 & Haingion & Henoshoun & Hans \\
\hline 17 & Lower filter & Polypropylene & 1 & 29.33 & 0.0014 & 0.0406 & Wakayama & Wakayama & Wakayama \\
\hline 18 & Protection cap & Polystyrene (ABS) & 1 & 22.29 & 0.0020 & 0.0437 & Whan & Whan & WNinan \\
\hline 20 & $\begin{array}{l}\text { Rubber of outer } \\
\text { flame of fan }\end{array}$ & Synthetic rubber & 1 & 22.85 & 0.0024 & 0.0556 & Qungda & Omgdao & Qmeda. \\
\hline 21 & Outer flame of fan & Aluminum alloy & 1 & 55.11 & 0.0021 & 0.1182 & Wadad & 2 & 2an \\
\hline 22 & Lower fan & Polypropylene & 1 & 15.08 & 0.0014 & 0.0209 & Yokohama & Yokohama & Yokohama \\
\hline 23 & Fan & Aluminum alloy & 1 & 62.1 & 0.0021 & 0.1332 & Nagoya & Mendogm & Mennghe \\
\hline \multicolumn{3}{|c|}{ Total } & 25 & 1421 & & & & & \\
\hline \multicolumn{3}{|c|}{ Average } & 1.09 & 61.78 & 0.0045 & 0.1428 & & & \\
\hline \multicolumn{7}{|c|}{ Explanatory notes: } & Japan & Nimat & Malaysta \\
\hline
\end{tabular}

\subsection{Comparison with Types of Materials}

By comparing the results of the suppliers and factory locations selection for products made of polypropylene and the aluminum alloy, we find that there is a small difference because the fluctuation in polypropylene price affects the supply chain network comparing to the price fluctuation of aluminum alloy. One of the reasons for this is that the part procurement cost is obtained by multiplying the material cost of a part by its weight [10]. Thus, the weight of the parts is an important consideration in selecting suppliers when the prices of materials fluctuate. In this study, the parts made of polypropylene have weights ranging from light $1.71[\mathrm{~g}]$ to heavy $179.8[\mathrm{~g}]$. On the other hand, there is very little difference in the weight of the various parts of the aluminum alloy. Therefore, the price fluctuation of polypropylene affects the network comparing to that of the aluminum alloy. 


\section{Results of Global Supply Chain Design Without Redesign Problem}

\subsection{Purpose of This Section}

Section 4 shows the result of suppliers and factory locations with redesign problem. However, the previous section does not show the result of suppliers and factory locations without a redesign problem. Therefore, in order to analyze the effect of the factory locations without the redesign problem and to compare the results of this study with the result of previous study [19], this section discusses the results without redesign problem in Nakamura et al. [19].

Assumptions in Nakamura et al. [19] are as follows:

- The factory opening $\operatorname{cost} F C_{a}$ in Japan, China and Malaysia are set as US\$100, US\$ 50 and US\$ 70, respectively.

- The customs duty rate on parts is $10 \%$ and on products is $25 \%$

\subsection{Results of Suppliers and Factory Locations without Redesign Problem}

Figure 2 shows the results of the suppliers and the factory locations selection with the default, with TPP and without TPP (Without redesign problem). In scenario A (without TPP), the factory is opened in China, and two Japanese suppliers and twenty Chinese suppliers are selected. On the other hand, in scenario B (with TPP), the factory is opened in Malaysia, and all suppliers are selected from Malaysia. The reason for the difference in supplier selection is that different factories are opened for each scenario. However, suppliers close to the factory are selected to reduce the transportation cost of parts.

In the result of supplier selection in section 4, there is a case where suppliers are selected for three countries. However, the similar result is not observed in the previous study [19]. The reason is that the location of the factory opened is different. Basically, suppliers close to the factory are selected to reduce the transportation cost of parts. However, when a factory is opened in Japan, procurement cost of parts in Japan becomes higher. Therefore, Chinese and Malaysia suppliers are selected for the parts with higher costs in section 4 .

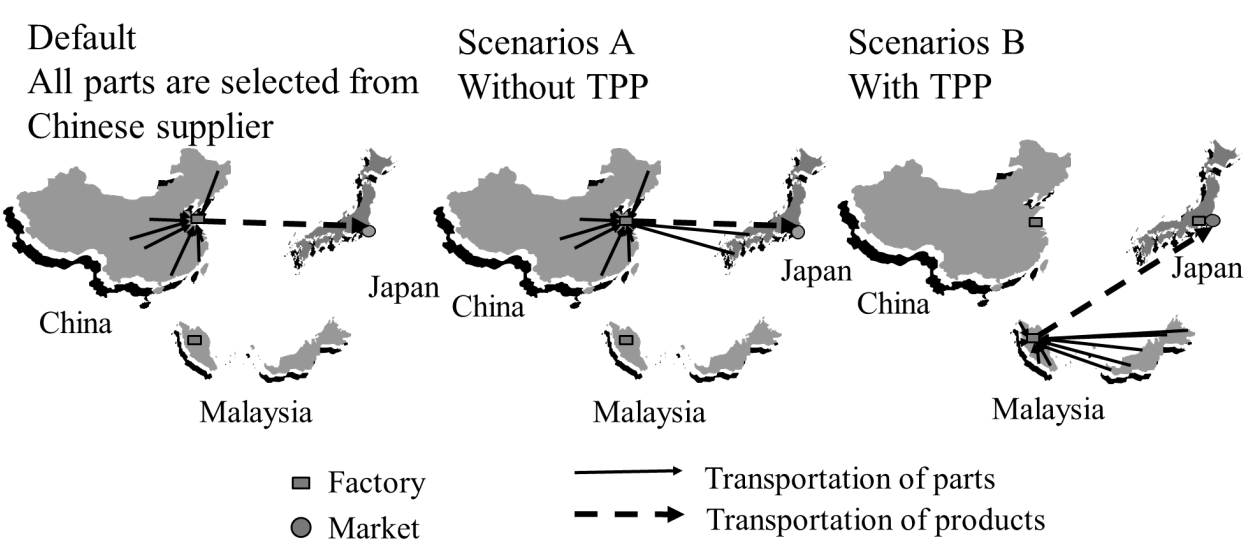

Figure 2: The results of the suppliers and the factory locations selection with the default, with TPP and without TPP (Without redesign problem) 


\section{Conclusions}

This study modeled the global supply chain network with customs duty and TPP, and analyzed the influence by fluctuating the material prices on the global supply chain network. The main conclusions observed in the experiments are as follows:

- Influence of TPP on supply chain network under material price fluctuation

When the prices of polypropylene doubled with TPP and without TPP, the total cost has a $0.1 \%$ difference by TPP. Under material price fluctuation, total cost due to supplier selection with TPP is less susceptible than one without TPP in this case. In this experiment, it was shown that supplier switching pattern by fluctuating material price differs depending on the new economic partnership agreement such as TPP. Therefore, international manufacturers need to consider FTAs in selecting suppliers to reduce costs more.

- Effect on supply chain network by material type

The price fluctuation of polypropylene affects the supply chain network comparing to the price fluctuation of aluminum alloy in this experiment. This is because, among of all parts, the weight range of the polypropylene parts are larger than aluminum alloy parts. From this result, it was quantitatively shown that the material with a wide range of weight among the parts included in the product is susceptible to the fluctuation of the material price.

- Redesign problem and factory location

Without the redesign problem, Japanese factory is not selected while parts are procured from suppliers close to each opened factory. By considering the redesign problem, there is a case that selected from all three country's suppliers in this study. From these results, it was shown the supplier selection depends on factory location for the purpose of cost minimization.

The contribution of this study is to show the resulted supply chain configuration and the changes in cost arising from external trading factors such as participation in TPP and material price fluctuation quantitatively.

Future works should conduct numerical experiments that cover other countries and FTAs. They should add exchange rate to this study model, and expand the method to formulate a multi-objective problem that includes $\mathrm{CO}_{2}$ saving rate.

\section{Acknowledgement}

This research was partially supported by the Japan Society for the Promotion of Science (JSPS), KAKENHI, Grant-in-Aid for Scientific Research (C), 16K01262 from 2016 to 2017 and for Scientific Research (A), JP18H03824, from 2018 to 2019. 


\section{References}

[1] Nihon Keizai Shimbun. Inc., TPP changes on business and living, Nihon Keizai Shimbun Publisher, 2016 (In Japanese).

[2] BBC, "EU and Japan reach free trade deal," July. 2017; http://www.bbc.com/news/business40520218 .

[3] Ministry of Foreign Affairs of Japan, Available at Free Trade Agreement (FTA) and Economic Partnership Agreement (EPA), http://www.mofa.go.jp/policy/economy/fta/index.html (Accessed on Feb. 24, 2017)

[4] Ministry of Foreign Affairs of Japan, Trans-Pacific Partnership (TPP) Negotiations, http://www.mofa.go.jp/mofaj/gaiko/tpp/, 2017 (Accessed on Sep. 30, 2017) (In Japanese).

[5] Diego A. Cerdeiro, "Estimating the Effects of the Trans-Pacific Partnership (TPP) on Latin America and the Caribbean (LAC)," May. 2016; https://www.imf.org/external/pubs/ft/wp/2016/wp16101.pdf., 2016 (Accessed on Sep. 30, 2017)

[6] Maurice Obstfeld, Gian Maria Milesi-Ferretti, and Rabah Arezki, "Oil Prices and the Global Economy: It's Complicated", https://blogs.imf.org/2016/03/24/oil-prices-and-the-globaleconomy-its-complicated/, 2016 (Accessed on Sep. 30, 2017).

[7] G. Salvendy, Handbook of Industrial Engineering, CA: John Wiley and Sons Inc, 1982.

[8] C. L. Munson and M. J. Rosenblatt, "The impact of local content rules on global souring decisions," Production and Operations Management, vol. 6, no. 3, 1997, pp. 277-289.

[9] T. Abdallah, A. Farhat, A. Diabat and S. Kennedy, "Green supply chain with carbon trading and environmental sourcing: Formulation and life cycle assessment," Applied Mathematical Modeling, vol. 36, 2012, pp. 4271-4285.

[10] T. Urata, T. Yamada, N. Itsubo and M. Inoue, "Global supply chain network design and Asian analysis with material-based carbon emissions and tax," Computers \& Industrial Engineering, vol. 113, 2017, pp. 779-792.

[11] M. A. Cohen and H. L. Lee, "Resource development analysis of global manufacturing \& distribution network," Journal of Manufacturing and Operations Management, vol. 2, 1989, pp. 81-104.

[12] H. S. Amin and F. Baki, "A facility location model for global closed-loop supply chain network design," Applied Mathematical Modeling, vol. 41, 2017, pp. 316-330.

[13] P. Tsiakis and G. L. Papageorgiou, "Optimal production allocation and distribution supply chain networks," International Journal of Production Economics, vol. 111, no. 2, 2008, pp. 468-483.

[14] J. Hosoda, K. Funaki, and T. Chida, "Recent issues in international supply chain network design - economic partnership modeling," In Fujisawa K., Shinano Y. and Waki H (Eds.), Optimization in the Real World. Tokyo: Springer, vol. 13, 2016, pp. 139-155. 
[15] A. M. Cohen, L. M. Fisher, and R. Jaikumar, "International manufacturing and distribution networks: a normative model framework," In Ferdows K. Ed. 26 Managing international manufacturing Amsterdam: Elsevier Science Publishers, 1989, pp. 67-93.

[16] C. J. Vidal and M. A. Goetschalckx, "Global supply chain model with transfer pricing and transportation cost allocation," European Journal of Operational Research, vol. 129, 2001, pp. 134-158.

[17] C. B. Arntzen, G. G. Brown, P. T. Harrison and L. L. Trafton, "Global supply chain management at digital equipment corporation,” Interfaces, vol. 25, 1995, pp. 69-93.

[18] K. Mariel and S. Minner, "Benders decomposition for a strategic network design problem under NAFTA local content requirements,” Omega, vol. 68, 2017, pp. 62-75.

[19] K. Nakamura, H. Ijuin, T. Yamada and M. Inoue, "Modeling for global supply chain network in consideration of TPP," the Society of Plant Engineers Japan, Autumn Meeting, Nagoya, Japan. November 2016, pp. 135-140 (In Japanese).

[20] K. Nakamura, H. Ijuin, T. Yamada, A. Ishigaki and M. Inoue, "Modeling of global supply chain network with Trans-Pacific Partnership," Journal of the Society of Plant Engineers Japan, vol. 30, no.3, 2018, pp. 69-81 (In Japanese).

[21] F. S. Hillier and G. J. Lieberman, Introduction to Operations Research, 8th Edition McGrawHill, 2005, pp.478-546.

[22] M. Inoue, T. Yamada and H. Ishikawa, "Life cycle design support system based on 3D-CAD for satisficing product performances and reduction of environmental loads at the early phase of design", Des. Eng, vol.49, no.10, 2014, pp. 543-549 (In Japanese).

[23] Numerical Optimizer, NTT DATA Mathematical Systems Inc., Available at http://www.msi.co.jp/nuopt/ (Accessed on Feb. 7, 2017)

[24] Y. Yoshizaki, T. Yamada, N. Itsubo and M. Inoue, "Material based low-carbon and economic supplier selection with estimation of $\mathrm{CO} 2$ emissions and cost using life cycle inventory database," Innovation and Supply Chain Management, vol. 8, no. 4, 2014, pp. 159-170. 